\title{
The Role of Entrepreneurial Motivation on Microcredit Terms'and Repayment Performance
}

\author{
Serafim Nogueira, Fábio Duarte and Ana Paula Gama
}

\begin{abstract}
Since its modern form, microcredit (MC) have been deemed as a viable instrument to alleviate poverty. Popularized in poor countries, its value has grown worldwide, being applied in developing and developed countries. This study examines the role of entrepreneurial motivation on credit terms' and repayment performance in the context of Portuguese microcredit industry. Using a portfolio of 2,060 microcredit applicants in Portugal between 1999-2015, our results show that Portuguese microcredit institutions lend higher amounts of credit with longer maturities to entrepreneurs who have lower likelihood of repayment (entrepreneurs moved by necessity). The focus on these riskier entrepreneurs led us to confirming the argument that $\mathrm{MC}$ is a prosocial instrument.
\end{abstract}

Keywords - microcredit, entrepreneurial motivation, prosocial funding instrument, Portugal.

\section{INTRODUCTION}

Access to financial resources has been often identified as one of the most important constraints reported by entrepreneurs when starting a business, especially in less developed countries [1]. Although literature still recognizing bank lending as the most commonly used form of finance by individual entrepreneurs and/or microenterprises [2], these entrepreneur-lender relationships often suffer from information asymmetries which might lead to market imperfections and, ultimately, to credit rationing [3], [4]. Lack of collateral and non-existent credit histories, coupled with high transaction costs, have led traditional banking system to neglect these individual entrepreneurs [5]. To solve some of these problems, new waves of entrepreneurial finance instruments emerged such as the case of the microcredit (MC) programs [6].

Born in poor countries, MC has grown into a worldwide industry. Literature in the topic has been a fast growing research area (mainly after the award of the Nobel Peace Prize to Prof. Yunus in 2006), and today is back in the spotlight after the 2019 Nobel Prize of Economics which recognizes the contribution of Abhijit Banerjee, Esther Duflo and Michael Kremer in the definition of anti-poverty policies, which includes MC lines.

In last decades, MC become a popular instrument as an innovative way to increase social and financial inclusion by

Serafim Nogueira, ESTG | P.PORTO, School of Technology and Management / Polytechnic of Porto, PORTUGAL.

FÁBIO DUARTE, ESTG | P.PORTO, School of Technology and Management / Polytechnic of Porto, PORTUGAL and CIICESI, Center for Innovation and Research in Business Sciences and Systems of Information.

ANA PAULA GAMA, NECE, UBI - Research Center in Business Sciences, University of Beira Interior, Covilhã, PORTUGAL. mitigating credit rationing [7], enabling entrepreneurial activity [8], [9], reducing poverty [10], and decreasing unemployment [11]. However, after decades of research, scholars continue focusing attentions on developing countries, where MC have been higher success. Additionally, empirical research on $\mathrm{MC}$ in Europe is scarce, mainly because in developed countries MC still addressing a niche market.1 We fill this empirical gap by extending the knowledge of MC lines and its characteristics on a European country - Portugal.

As point out by [7], MC may be an instrument not only to alleviate extreme poverty by also to promote microenterprises creation as a path to social and financial inclusion, minorities empowerment and job creation. Hence, in one hand, MC can be a good promoter of the transition from unemployment (or low-paid employment) to self-employment. On the other hand, MC can provide financing to entrepreneurs, who have started a business but have limited capital or credit history [12], that recognizes on the MC an opportunity to fulfil a dream. In this study we address this puzzle by analysing how microentrepreneur's motivation influences the credit terms and the repayment performance of MC loans. Studying these two types of entrepreneurs - motivated by opportunity versus motivated by necessity - and the link with credit terms and loan performance we aim to shed more light on the pro social orientation of MC.

\section{LITERATURE REVIEW AND EMPIRICAL HYPOTHESES}

\section{A. Microcredit Overview}

Literature on MC has been a fast growing research area [13], mainly since that Muhammad Yunus (the founder of Grameen Bank and one of the modern MC' pioneers) won the Nobel Prize of Peace in 2006. After the success of Yunus's field experiments in Bangladesh in the 1970s, MC has been widely presented as the solution to reduce poverty [10]. In emerging and developed countries, MC is also considered a dynamic instrument to mitigate social and financial exclusion and to empower minorities. By providing access to credit for the so-called non-bankable borrowers, MC targets informal entrepreneurs and/or microenterprises who do not have access to traditional banks, often because they are enabled to offer enough collateral [14]. By making available small loans to low-income people, mainly in emerging countries, $\mathrm{MC}$ allows the poor to start or expand their entrepreneurial activities, and thus, escape to the poverty cycle.

Despite the merits widely attributed to $\mathrm{MC}$, the pressure for 
greater sustainability of MC lines may deviate this instrument from its purpose: reach the poorest.2 Initially dominated by subsidized institutions, several commercial lenders emerged in the MC domain in the last decade. In consequence, it is possible identify two main types of MC institutions: i) those that are publicly subsided and follows a prosocial approach, and; ii) those that are part of the traditional financial system and therefore pursue the sustainability of their operations. Empirically, the academic community studying the topic provides mixed results on the determinants and impacts of MC, casting doubt on the real value of MC to improve entrepreneurs' financial well-being. Hence, a better understanding of this changing paradigm - from a development-based view to a market-based view [15] - can provide clues to building a more efficient MC industry.

\section{B. Microcredit and Entrepreneurial Motivation}

Despite recent research interest on the topic, the entrepreneurship remains poorly studied in the MC context [16]. This question is particularly relevant in developed countries, where MC institutions have been sought by a wide audience: if on the one hand, MC aims alleviate poverty, improving the empowerment of socially and financial excluded persons, on the other, it provides extra funding to entrepreneurs, mostly micro-entrepreneurs, who face problems with access to traditional funds for starting up or expanding their micro-business. Hence, as suggested by [17], the MC's industry seek to understand how entrepreneurs motivation relates with MC performance, reaching its beneficiaries more efficiently.

Global Entrepreneurship Monitor (GEM) distinguishes entrepreneurs based on their motivations: entrepreneurs by necessity or by the opportunity.3 Entrepreneurs moved by opportunity are seen as those who start a business in order to take advantage of a new idea or business prospect [18], [19]; they are moved by the challenge and the potential rewards (mainly non-pecuniary), such as more independence, autonomy, self-fulfilment, or skill utilization [20]-[24]. Motivated by non-pecuniary benefits, entrepreneurs by opportunity are strongly involved with the project. According to [25], they tend to undertake more profitable projects than entrepreneurs moved by necessity. Entrepreneurs moved by necessity are forced to start a business to meet economic needs and survive to unemployment [26], [27]; also called entrepreneurs against their will [28] or subsistence entrepreneurs [29], they are driven by monetary motivations. Since entrepreneurs by opportunity traditionally have an extra-business source of professional income, which allows them to more easily accumulate personal savings when compared to entrepreneurs moved by necessity, these entrepreneurs can repay their loans easier than entrepreneurs by necessity. For the same reasons, they tend to request smaller amounts of credit as well as lower maturities, contrary to entrepreneurs by necessity who will try to exhaust the credit terms (higher amounts of credit with longer maturities).

Hence, based on previous arguments we formulate the following hypotheses:
H1: Entrepreneurs by necessity (EN) has lower likelihood of repayment;

H2: Entrepreneurs by necessity (EN) receive higher amounts of credit;

H3: Entrepreneurs by necessity (EN) receive credit with long maturities.

\section{DATA AND VARIABLES}

\section{A. Data}

This study uses data from the first MC institution founded in Portugal - ANDC.4 Over the 1999-2015 period, this institution awarded 2,060 micro-loans amounting to a total of 13.2 million euros. The data set was created using the client portfolios and identifies several characteristics of the entrepreneurs, characteristics related to the business/project, the terms on which the credit was provided, and the final repayment status of entrepreneurs' microcredit process.

\section{B. Variables}

\section{Dependent variable}

REPAYMENT is a binary variable that takes a value of 1 if the credit of borrower was repaid without any credit event and 0 otherwise. LSIZE is the natural logarithm of the amount of loan received. LMATURITY is the natural logarithm of the time (in months) in which the full amount of loans must be repaid.

Table 1 reports the descriptive statistics. This table shows that $65,3 \%$ of the entrepreneurs in our data set are entrepreneurs moved by necessity, in line with [12]. The data set includes 1,307 loans already closed, where almost $84 \%$ was repaid without any credit event. The mean value of the loans granted is EUR 6,398.31 and the mean of the time in which the full amount of loans was repaid is 43 months.

\section{Independent variables}

Entrepreneur Motivation is measured by the variable Entrepreneur by Necessity which is a binary variable that takes the value 1 if the entrepreneur is forced to start a business to meet economic needs and survive to unemployment [26], [27], and 0 if is an entrepreneur by opportunity (i.e., to full fill a dream)

Entrepreneur characteristics includes its gender (Female), a binary variable equals 1 if the entrepreneur is female, and 0 otherwise [30], [31]; entrepreneur's age (Age), measured in years [12], [32]; educational level (Literacy), a categoric variable that range from 3 (junior school) to 1 (university) [30]; marital status (Marital Status), a binary variable equals 1 if the entrepreneur is married or committed and zero otherwise [30], [33]; and nationality (Portuguese borrower), a binary variable equals 1 if the entrepreneur is Portuguese citizen and 0 if it is foreigner [34].

Business Characteristics are measured by the variable Labour Intensive Sector which represents the average of employed population over total employed population by activity sector (primary, secondary or tertiary sector). 


\section{Methodology}

To test our hypothesis H1, in line with [12], this paper uses a Probit model expressed as follows:

REPAYMENT $_{i}=\beta_{1}$ Entrepreneur Motivation $_{i}+\beta_{2}$ Entrepreneur Characteristics $_{i}+$

$\beta_{3}$ Business Characteristics ${ }_{i}+\beta_{4}$ Credit Terms $_{i}+\varepsilon_{i}$ for $\mathrm{i}=1, \ldots, \mathrm{n}$

To test $\mathrm{H} 2$ and $\mathrm{H} 3$, in line with [30], [35], [44] we test the following two models using an OLS regression:

LSIZE $_{i}=\beta_{0}+\beta_{1}$ Entrepreneur Motivation $_{i}+\beta_{2}$ Entrepreneur Characteristics $_{i}+$

$\beta_{3}$ Business Characteristics $_{i}+\beta_{4}$ Credit Terms $_{i}+\varepsilon_{i}$ for $i=1, \ldots, n$

(eq.2)

LMATURITY $_{i}=\beta_{0}+\beta_{1}$ Entrepreneur Motivation $_{i}+\beta_{2}$ Entrepreneur Characteristics $_{i}+$ $\beta_{3}$ Business Characteristics $_{i}+\beta_{4}$ Credit Terms $_{i}+\varepsilon_{i}$ for $i=1, \ldots, n$

(eq.3)

\section{PRELIMINARY RESULTS}

Table 2 - Panel A reports baseline Probit estimations about role of entrepreneurial motivation on credit repayment (Eq.1). 6 The negative coefficients of entrepreneur by necessity ( $p$-value $<0.10$ ) suggest that entrepreneurs moved by necessity are less likely to repay their loan than them moved by opportunity confirming H1, in line with [12], [36]. Portuguese entrepreneurs are more literate and are more likely to repay their loans on time. Oppositely, entrepreneurs operating in labour intensive sectors or who present larger loans has lower likelihood of repayment.

Table 2 - Panels B and C reports baseline estimations about role of entrepreneurial motivation on loan terms (Eq. 2 and 3, respectively). 7 The results broadly support our hypotheses $\mathrm{H} 2$ and H3 (p-value $<0.01$ ) in contrast with the findings of [30]. In line with our predictions, these results suggest that $\mathrm{MC}$ tend to sponsor riskier entrepreneurs. Additionally, we find evidences that higher loan amounts are granted for female entrepreneurs and for those more literate. Older entrepreneurs, with higher levels of literacy, married or committed, with Portuguese nationality receive longer maturities.

\section{CONCLUSIONS}

Since it's modern form, microcredit have been deemed as a viable instrument to alleviate poverty. Popularized in poor countries to fight against extreme poverty, $\mathrm{MC}$ is starting to gain a momentum in developed countries as an instrument to mitigate social and financial exclusion of specific population groups. However, despite MC's success, there has been little research on the impact or depth of MC institutions outreach [37], and most research focuses on developing countries. Although we can find some studies on the credit terms and loan performance of commercial bank lending in Portugal (e.g., [44], [45]), to the best of our knowledge, this study is the first that investigates the role of entrepreneurial motivation on credit terms' and repayment performance in the context of Portuguese microcredit industry.

We found that entrepreneurial motivation has a significant effect on the credit repayment. Entrepreneurs moved by necessity show lower repayment rate than those moved by the opportunity. Despite increasing pressure on MC institutions to reduce its dependency of subsidies our findings suggest that, overall, Portuguese MC institutions targets a specific group of riskier individuals who receive longer maturities and higher amount of credit. These evidences support the view of MC as a pro-social instrument.

\section{REFERENCES}

[1] J. Stiglitz, "Peer Monitoring and Credit Markets," World Bank Econ. Rev., vol. 4, no. 3, pp. 351-366, 1990. https://doi.org/10.1093/wber/4.3.351

[2] A. N. Berger and G. F. Udell, "Relationship Lending and Lines of Credit in Small Firm Finance,” J. Bus., vol. 68, no. 3, p. 351, Jan. 1995. https://doi.org/10.1086/296668

[3] J. Stiglitz and A. Weiss, "Credit rationing in markets with imperfect information," Am. Econ. Rev., vol. 71, no. 3, pp. 393-410, 1981.

[4] A. P. M. Gama and H. Van Auken, "The Interdependence between Trade Credit and Bank Lending: Commitment in Intermediary Firm Relationships,” J. Small Bus. Manag., vol. 53, no. 4, pp. 886-904, Oct. 2015. https://doi.org/10.1111/jsbm.12115

[5] F. Duarte, A. P. M. Gama, and J. P. Esperança, "The Role of Collateral in the Credit Acquisition Process: Evidence from SME Lending," J. Bus. Financ. Account., vol. 43, no. 5-6, pp. 693-728, May 2016. https://doi.org/10.1111/jbfa.12207

[6] G. D. Bruton, S. Khavul, D. Siegel, and M. Wright, "New Financial Alternatives in Seeding Entrepreneurship: Microfinance, Crowdfunding, and Peer-to-Peer Innovations," Entrep. Theory Pract., vol. 39, no. 1, pp. 9-26, Jan. 2015. https://doi.org/10.1111/etap.12143

[7] M. Bendig, M. Unterberg, and B. Sarpong, EMN Policy Note on the EMN Overview of the Microcredit Sector in the European Union 2012-13. Brussels: European Microfinance Network, 2014.

[8] G. D. Bruton, S. Khavul, and H. Chavez, "Microlending in emerging economies: Building a new line of inquiry from the ground up," J. Int. Bus. Stud., vol. 42, no. 5, pp. 718-739, Jun. 2011. https://doi.org/10.1057/jibs.2010.58

[9] G. D. Bruton, D. J. Ketchen, and R. D. Ireland, "Entrepreneurship as a solution to poverty," J. Bus. Ventur., vol. 28, no. 6, pp. 683-689, Nov. 2013

https://doi.org/10.1016/j.jbusvent.2013.05.002

[10] S. R. Khandker, "Microfinance and Poverty: Evidence Using Panel Data from Bangladesh," World Bank Econ. Rev., vol. 19, no. 2, pp. 263-286, Aug. 2005. https://doi.org/10.1093/wber/lhi008

[11] M. Yunus, "Banker to the Poor: the Autobiography of Muhammad Yunus the Founder of the Grameen Bank." Dhaka University Press, 1998

[12] R. Bourlès and A. Cozarenco, "Entrepreneurial motivation and business performance: evidence from a French Microfinance Institution," Small Bus. Econ., vol. 51, no. 4, pp. 943-963, Dec. 2018. https://doi.org/10.1007/s11187-017-9961-8

[13] C. Milana and A. Ashta, "Developing microfinance: A survey of the literature," Strateg. Chang., vol. 21, no. 7-8, pp. 299-330, Nov. 2012. https://doi.org/10.1002/jsc.1911

[14] M. Yunus, Banker to the poor: Micro-lending and the battle against world poverty. PublicAffairs, 2007

[15] S. Khavul, H. Chavez, and G. D. Bruton, "When institutional change outruns the change agent: The contested terrain of entrepreneurial microfinance for those in poverty," J. Bus. Ventur., vol. 28, no. 1, pp. 30-50, Jan. 2013. https://doi.org/10.1016/j.jbusvent.2012.02.005

[16] A. Newman, S. Schwarz, and D. Borgia, "How does microfinance enhance entrepreneurial outcomes in emerging economies? The mediating mechanisms of psychological and social capital," Int. Small Bus. J. Res. Entrep., vol. 32, no. 2, pp. 158-179, Mar. 2014. https://doi.org/10.1177/0266242613485611

[17] E. Duflo, "Microcrédit, miracle ou désastre?," Probl. Econ., no. 3027, p. 10,2011

[18] I. M. Kirzner, Competition and entrepreneurship. University of Chicago press, 2015.

[19] J. Kirkwood, "Motivational factors in a push-pull theory of entrepreneurship," Gend. Manag. An Int. J., vol. 24, no. 5, pp. 346-364, Jul. 2009.

https://doi.org/10.1108/17542410910968805 
[20] M. P. Taylor, "Earnings, independence or unemployment: why become self-employed?," Oxf. Bull. Econ. Stat., vol. 58, no. 2, pp. 253-266, May 1996. https://doi.org/10.1111/j.1468-0084.1996.mp58002003.x

[21] C. Dalborg and J. Wincent, "The idea is not enough: The role of self-efficacy in mediating the relationship between pull entrepreneurship and founder passion - a research note," Int. Small Bus. J. Res. Entrep., vol. 33, no. 8, pp. 974-984, Dec. 2015. https://doi.org/10.1177/0266242614543336

[22] M. Benz and B. S. Frey, "Being independent is a great thing: Subjective evaluations of self-employment and hierarchy," Economica, 2008. https://doi.org/10.1111/j.1468-0335.2007.00594.x

[23] G. Hundley, "Why and When Are the Self-Employed More Satisfied with Their Work?," Ind. Relations A J. Econ. Soc., vol. 40, no. 2, pp. 293-316, Apr. 2001. https://doi.org/10.1111/0019-8676.00209

[24] T. Lange, "Job satisfaction and self-employment: autonomy or personality?," Small Bus. Econ., vol. 38, no. 2, pp. 165-177, Feb. 2012. https://doi.org/10.1007/s11187-009-9249-8

[25] J. H. Block and M. Wagner, "Necessity and Opportunity Entrepreneurs in Germany: Characteristics and Earning s Differentials," Schmalenbach Bus. Rev., vol. 62, no. 2, pp. 154-174, Apr. 2010. https://doi.org/10.1007/BF03396803

[26] B. Gilad and P. Levine, "A behavioral model of entrepreneurial supply," J. small Bus. Manag., vol. 24, p. 45, 1986.

[27] H. Bergmann and R. Sternberg, "The Changing Face of Entrepreneurship in Germany," Small Bus. Econ., vol. 28, no. 2-3, pp. 205-221, Feb. 2007. https://doi.org/10.1007/s11187-006-9016-z

[28] C. Korunka, H. Frank, M. Lueger, and J. Mugler, "The Entrepreneurial Personality in the Context of Resources, Environment, and the Startup Process-A Configurational Approach," Entrep. Theory Pract., vol. 28, no. 1, pp. 23- 42, Sep. 2003. https://doi.org/10.1007/s11187-006-9016-Z

[29] A. Jaouen and F. Lasch, "A new typology of micro-firm owner-managers," Int. Small Bus. J. Res. Entrep., vol. 33, no. 4, pp. 397-421, Jun. 2015. https://doi.org/10.1007/s11187-006-9016-z

[30] S. Brana, "Microcredit: an answer to the gender problem in funding?," Small Bus. Econ., vol. 40, no. 1, pp. 87-100, Jan. 2013. https://doi.org/10.1007/s11187-006-9016-Z

[31] T. W. Moss, D. O. Neubaum, and M. Meyskens, "The Effect of Virtuous and Entrepreneurial Orientations on Microfinance Lending and Repayment: A Signaling Theory Perspective," Entrep. Theory Pract., vol. 39 , no. 1, pp. 27-52, Jan. 2015. https://doi.org/10.1007/s11187-006-9016-z

[32] D. R. Mason, "Who gets what? Determinants of loan size and credit rationing among microcredit borrowers: Evidence from Nicaragua," J. Int. Dev., vol. 26, no. 1, pp. 77-90, Jan. 2014. https://doi.org/10.1007/s11187-006-9016-Z
[33] T. H. T. Dinh and S. Kleimeier, "A credit scoring model for Vietnam's retail banking market," Int. Rev. Financ. Anal., vol. 16, no. 5, pp. 471-495, Jan. 2007. https://doi.org/10.1007/s11187-006-9016-z

[34] J. Bruder, D. Neuberger, and S. Räthke-Döppner, "Financial constraints of ethnic entrepreneurship: evidence from Germany," Int. J. Entrep. Behav. Res., vol. 17, no. 3, pp. 296-313, May 2011. https://doi.org/10.1007/s11187-006-9016-z

[35] K. Kirschenmann and L. Norden, "The Relationship between Borrower Risk and Loan Maturity in Small Business Lending," J. Bus. Financ. Account., p. no-no, Apr. 2012 https://doi.org/10.1007/s11187-006-9016-z

[36] U. Vogelgesang, "Microfinance in Times of Crisis: The Effects of Competition, Rising Indebtedness, and Economic Crisis on Repayment Behavior," World Dev., vol. 31, no. 12, pp. 2085-2114, Dec. 2003. https://doi.org/10.1007/s11187-006-9016-Z

[37] V. Hartarska, "Governance and performance of microfinance institutions in Central and Eastern Europe and the Newly Independent States," World Dev., vol. 33, no. 10, pp. 1627-1643, Oct. 2005. https://doi.org/10.1007/s11187-006-9016-z

[38] L. R. Reed, J. Marsden, C. Rivera, A. Ortega, and S. Rogers, "Resilience: The state of the Microcredit Summit Campaign report, 2014," Washington, DC Microcredit Summit Campaign, 2014.

[39] R. Mersland and R. Ø. Strøm, "Microfinance Mission Drift?," World Dev., vol. 38, no. 1, pp. 28-36, Jan. 2010. https://doi.org/10.1007/s11187-006-9016-z

[40] R. Amit and E. Muller, "Push' and 'pull' entrepreneurship," J. Small Bus. Entrep., vol. 12, no. 4, pp. 64-80, Jan. 1995. https://doi.org/10.1007/s11187-006-9016-z

[41] O. Giacomin, F. Janssen, M. Pruett, R. S. Shinnar, F. Llopis, and B. Toney, "Entrepreneurial intentions, motivations and barriers: Differences among American, Asian and European students," Int. Entrep. Manag. J., vol. 7, no. 2, pp. 219-238, Jun. 2011 https://doi.org/10.1007/s11187-006-9016-Z

[42] P. Van der Zwan, R. Thurik, I. Verheul, and J. Hessels, "Factors influencing the entrepreneurial engagement of opportunity and necessity entrepreneurs," Eurasian Bus. Rev., 2016. https://doi.org/10.1007/s11187-006-9016-z

[43] J. Mota, A. C. Moreira, and C. Brandão, "Determinants of microcredit repayment in Portugal: analysis of borrowers, loans and business projects," Port. Econ. J., vol. 17, no. 3, pp. 141-171, Nov. 2018. https://doi.org/10.1007/s11187-006-9016-z

[44] F. Duarte, A.P.M. Gama, and M. A. Gulamhussen, "Credit risk, owner liability, and bank loan maturities during the global financial crisis." Eur Financ Manag, Oct 2019. https://doi.org/10.1007/s11187-006-9016-z

[45] F. Duarte, A.P.M. Gama, and M. A. Gulamhussen "Defaults in bank loans to SMEs during the financial crisis." Small Bus Econ vol 51, no. 3, pp. 591-608, 2018 https://doi.org/10.1007/s11187-006-9016-z 
TABLE I. DESCRIPTIVE STATISTICS

\begin{tabular}{|c|c|c|c|c|c|}
\hline Variables & Observations & Mean & Std. Dev. & Min. & Max. \\
\hline \multicolumn{6}{|l|}{ Dependent } \\
\hline Repayment & 1307 & 0.832 & 0.374 & 0 & 1 \\
\hline Size & 2059 & 6398.315 & 2910.341 & 998 & 20000 \\
\hline Maturity & 2060 & 43.007 & 9.875 & 15 & 84 \\
\hline \multicolumn{6}{|l|}{ Independent } \\
\hline \multicolumn{6}{|l|}{ Entrepreneur Motivation } \\
\hline Entrepreneur by Necessity & 1440 & 0.653 & 0.476 & 0 & 1 \\
\hline \multicolumn{6}{|l|}{ Entrepreneur Characteristics } \\
\hline Female & 2060 & 0.486 & 0.500 & 0 & 1 \\
\hline Age & 2058 & 36.348 & 10.338 & 18 & 72 \\
\hline \multicolumn{6}{|l|}{ Literacy } \\
\hline University & 2025 & 0.173 & 0.378 & 0 & 1 \\
\hline High School (control) & 2025 & 0.383 & 0.486 & 0 & 1 \\
\hline Junior School & 2025 & 0.444 & 0.497 & 0 & 1 \\
\hline Marital Status & 1980 & 0.320 & 0.467 & 0 & 1 \\
\hline Portuguese Borrower & 2060 & 0.961 & 0.194 & 0 & 1 \\
\hline \multicolumn{6}{|l|}{ Business Characteristics } \\
\hline Labour Intensive Sector & 2060 & 0.529 & 0.135 & 0.114 & 0.591 \\
\hline
\end{tabular}

TABLE II. BASELINE ESTIMATIONS

\begin{tabular}{|c|c|c|c|c|c|c|c|}
\hline & \multicolumn{3}{|c|}{$\begin{array}{c}\text { Panel A } \\
\text { Dependent Variable: } \\
\text { REPAYMENT }\end{array}$} & \multicolumn{2}{|c|}{$\begin{array}{c}\text { Panel B } \\
\text { Dependent Variable: } \\
\text { LSIZE }\end{array}$} & \multicolumn{2}{|c|}{$\begin{array}{c}\text { Panel C } \\
\text { Dependent Variable: } \\
\text { LMATURITY }\end{array}$} \\
\hline & \multicolumn{3}{|c|}{ Method: } & \multicolumn{2}{|c|}{ Method: } & \multicolumn{2}{|c|}{$\begin{array}{l}\text { Method: } \\
\text { OIS }\end{array}$} \\
\hline & A.1 & A. 2 & A.3 & B.1 & B.2 & C.1 & C.2 \\
\hline \multicolumn{8}{|l|}{ Entreprencur Motrivation } \\
\hline Entrepreneur by Necessity & $\begin{array}{c}-0.309 * *+ \\
(0.113)\end{array}$ & $\begin{array}{l}-0.223^{+} \\
(0.118)\end{array}$ & $\begin{array}{c}-0.248^{* t} \\
(0.117)\end{array}$ & $\begin{array}{c}0.189 * * t \\
(0.026)\end{array}$ & $\begin{array}{c}0.059 \cdots+\cdots \\
(0.023)\end{array}$ & $\begin{array}{c}0.101^{\text {t*t }} \\
(0.012)\end{array}$ & $\begin{array}{c}0.058^{*+*} \\
(0.010)\end{array}$ \\
\hline \multicolumn{8}{|l|}{ Entropreneur Charactoristics } \\
\hline Female & & $\begin{array}{l}-0.032 \\
(0.113)\end{array}$ & $\begin{array}{l}-0.058 \\
(0.112)\end{array}$ & & $\begin{array}{c}0.086^{\cdots+*} \\
(0.021)\end{array}$ & & $\begin{array}{l}-0.002 \\
(0.010)\end{array}$ \\
\hline \multirow[t]{2}{*}{ Age } & & 0.002 & 0.003 & & -0.002 & & $0.001^{\text {th }}$ \\
\hline & & $(0.006)$ & $(0.006)$ & & $(0.001)$ & & $(0.000)$ \\
\hline \multicolumn{8}{|l|}{ Literacy } \\
\hline \multirow[t]{2}{*}{ University } & & $0.565^{\text {*at }}$ & $0.560^{\text {*at }}$ & & $0.062^{*+}$ & & $0.026^{*}$ \\
\hline & & $(0.203)$ & $(0.204)$ & & $(0.029)$ & & $(0.013)$ \\
\hline \multirow[t]{2}{*}{ Jumior School } & & 0.004 & 0.007 & & -0.011 & & $-0.048^{\text {tho }}$ \\
\hline & & $(0.122)$ & $(0.122)$ & & $(0.024)$ & & $(0.011)$ \\
\hline \multirow[t]{2}{*}{ Marital Status } & & 0.207 & 0.187 & & 0.025 & & $0.033^{\text {*t*t }}$ \\
\hline & & $(0.131)$ & $(0.131)$ & & $(0.023)$ & & $(0.010)$ \\
\hline \multirow[t]{2}{*}{ Portuguese Borrower } & & $0.402^{*}$ & $0.424^{*}$ & & -0.011 & & $0.076^{*+*}$ \\
\hline & & $(0.230)$ & $(0.231)$ & & $(0.054)$ & & $(0.024)$ \\
\hline \multicolumn{8}{|l|}{ Business Characteristics } \\
\hline \multirow[t]{2}{*}{ Labour Intensive Sector } & & $-1.045^{* *}$ & $-1.014^{* t *}$ & & -0.048 & & -0.001 \\
\hline & & $(0.503)$ & $(0.502)$ & & $(0.082)$ & & $(0.037)$ \\
\hline \multicolumn{8}{|l|}{ Credit Terms } \\
\hline \multirow[t]{2}{*}{$\ln ($ Size) } & & $-0.282^{* * *}$ & & & & & $0.225^{\text {*t*t }}$ \\
\hline & & $(0.136)$ & & & & & $(0.010)$ \\
\hline \multirow[t]{2}{*}{$\ln ($ Maturity) } & & & -0.525 & & $1.113^{* * *}$ & & \\
\hline & & & $(0.380)$ & & $(0.052)$ & & \\
\hline \multirow[t]{2}{*}{ Constant } & $1.165^{\text {t+* }}$ & $3.561^{\text {th }}$ & $3.028^{*+}$ & $8.637^{\star * *}$ & $4.544^{\text {*n* }}$ & $3.728^{*+* t}$ & $1.677^{*+\infty}$ \\
\hline & $(0.089)$ & $(1.248)$ & $(1.438)$ & $(0.021)$ & $(0.204)$ & $(0.009)$ & $(0.097)$ \\
\hline Observations & 767 & 752 & 752 & 1440 & 1405 & 1440 & 1405 \\
\hline R-Squared & & & & 0.034 & 0.306 & 0.050 & 0.331 \\
\hline
\end{tabular}

